\title{
DEPENDENCE BETWEEN COMPETITIVENESS AND TAX INDICATORS BASED ON COMPETITIVENESS REPORTS
}

\author{
[Závislost mezi konkurenceschopností a daňovými indikátory dle žebříčků \\ konkurenceschopnosti]
}

\author{
Jan Tecl ${ }^{1}$ \\ ${ }^{1}$ University of economics in Prague, Faculty of finance and accounting, nám. W. Churchilla 4, 13067 Praha 3 \\ Email: xtecj02@vse.cz
}

\begin{abstract}
This paper deals with dependence between the overall value of competitiveness from world ranks and tax variables with focus on the labor taxation. The analysis is carried out for the period between 2014 and 2016 as the regression analysis. Based on current literature, there is a relationship between competitiveness and taxation. Assumption is that a country has higher competitiveness with a lower tax rate. The results show, that there is a statistically significant relationship between competitiveness and tax variables. A relationship in line with expectation was found between competitiveness and effect of taxation on incentives to work. In another test, consumption tax was statistically significant. In case of tests with variables from the OECD (tax rates), there was found a statistically significant relationship with a personal income tax combined with social security payments, but the relationship was opposite to the expected one.
\end{abstract}

Keywords: competitiveness, labor taxation, taxation, world-wide competitiveness ranks.

JEL classification: $\mathrm{H} 20$

Doručeno redakci: 9.5.2018; Recenzováno: 21.5.2018; 1.6.2018; Schváleno k publikování: 13.6.2018

\section{Introduction}

How important is the effect of taxation for entrepreneurial subjects when they decide to start their business activity in a foreign country? Is there a close relationship between competitiveness of a country and country's tax system and its characteristics? Or do the subjects not care for taxation when they choose jurisdiction of their activity?

Generally, the tax system has some influence on country's competitiveness or generally speaking how attractive the country is for its inhabitants and investors. Productive factors labor and capital - are generally considered mobile productive factors, so they can be transferred from the country of origin to another country with a more favorable tax regime. The tax system and its characteristics is not the single factor important for decision making on place of investment or establishment of subjects. However, it has some influence on the decision making process on subsequent transfer of the place of business.

The term competitiveness is commonly used for comparison of countries, but some authors discuss whether the term competitiveness could even be used for countries or whether it can be used only for companies (Krugman 1994, Malý 2011). Despite the strict opinions, many organizations (non-profit organizations, banks, governments, etc.) and also many papers try to describe or measure competitiveness of the country.

Each organization, which measures competitiveness of a countries, uses its own definition of competitiveness and also own methodology and data source and data weight. However, the data on taxation in a given country is usually used as the key input data when measuring competitiveness. 
The World Competitiveness Yearbook (issued by IMD) (hereinafter the WCY) and the Global Competitiveness Report (hereinafter the GCR) (issued by the WEF, the World Economic Forum) belong to among globally recognized studies and ranks of competitiveness.

The aim of this paper is to analyze the relation between the country's competitiveness and tax variables. There is an assumption, that there is a significant relationship between country's competitiveness and its tax variables. This relationship should be negative (based on the literature review), i.e. higher competitiveness is a result of lower taxation. If an individual or an investor requests a given net income, the target gross income differs because of the amount of tax paid. Based on this argument, the corporate income tax should have negative impact on competitiveness. However, tax revenue allows governments to maintain expenditures for well being. So the overall impact in fact is not obvious. A deeper analysis will be carried out in the influence of the taxation of labor, as this is a main area of my research.

This paper thus analyses the relation between the total value of competitiveness based on world competitiveness ranks and tax indicators for the period between 2014 and 2016. This analysis will be carried out for all countries for which data is available from the GCR, the WCY, the ITC, and the OECD.

\section{Relationship between competitiveness and taxation}

Competitiveness of a country is derived from the extent to which the country is able to compete with other countries. Competition can also take place in the field of taxation. There are many authors who describe tax competition (Wilson 1999) and some of them also tried to quantify the competitiveness (Liapis et al. 2014). There are also papers that discuss tax competition in case of a different size of the countries compared (Kanbur and Keen 1993). There are also models in which reduction of tax rate can lead to the situation in which some workers leave the country with a lower tax rate than the hypothetical tax rate in case of closed borders(Smith and Webb 2001).

The result of a country's competition with other countries can be described as competitiveness. Although the term competitiveness (in meaning of country's competitiveness) is used by economists, researchers, politicians and public, there is no consensus on the definition of the country's competitiveness. Some of the country's competitiveness definitions were summarized by Cellini and Soci (2002). The goal of this paper is not to establish a definition of competitiveness, but the shift in the understanding of competitiveness will be briefly outlined.

A significant shift in the development of the definition of competitiveness took place over the decades. Previously, the so-called external concept had been used for the definition of competitiveness. Competitiveness was understood by Balassa (1964)as state's ability to succeed in the domestic and foreign markets due to the development of affordable-cost factors. This definition is focused only on the business concept of competitiveness. However, quality of living and other factors affecting inhabitants' lives, among the others, are not taken into account. Also, the amount of investments in the given country is not important for this definition.

The shift in the definition that also considers quality of living was made by Tyson (1993) as ability to produce goods and services that meet the test of international competition while our citizens enjoy a standard of living that is both rising and sustainable. This definition already reflects also the situation of the population (compared to the previously mentioned definition). Based on the project Competitiveness under New Perspectives (Aiginger et al. 2013) held by the European Union, the competitiveness is newly defined as ability of a country (region, 
location) to deliver the beyond-GDP goals for its citizens today and tomorrow. This definition leaves the output behind other factors that are more important to country's citizens. However, the economic output of the country is still important, because it helps to reach other goals.

Taxation is one of the key factors used in world-wide competitiveness reports. There are also papers focused on the relationship between competitiveness and taxation. Based on the Johansson et al. (2008), in open economies the design of a national tax system will need to consider the design of tax systems in other countries, since countries are increasingly using their tax systems to improve their ability to compete in global markets.

Some authors also tried to find a relationship between the economic growth and impact of taxation. One of the first papers in this topic belongs to Judd (1985) and Barro (1998). The impact of different kinds of taxes was a subject of an analysis carried by Johansson et al. (2008); the conclusion is that the economic growth is mostly affected by the corporate and income taxes. The negative effect of the corporate income tax (average and marginal) on the economic growth in the EU was concluded by Baranova and Janickova (2012).

\section{a. World-wide competitiveness ranks}

There are 2 well known competitiveness ranks in the world - The Global Competitiveness Report issued by the World Economic Forum and the World Competitiveness Yearbook issued by the International Institute for Management Development. The mentioned reports take into consideration many factors which could have impact on competitiveness. The impact of taxation on country's competitiveness is covered in both ranks.

These ranks are also criticized because of certain standards according to which competitiveness is measured and which do not consider all differences and options of the country (Pârtachi and Gârla 2016) or the effects are considered only in long run instead of taking into account also short or middle run (Djogo and Stanisic 2016). The mentioned studies have its origin in the eastern or south-eastern Europe. Authors of these papers try to find their own measurement methodology for competitiveness. Based on the results, their home countries have higher competitiveness than in the world-wide competitiveness reports.

On the other hand, there are also other ranks which measure competitiveness in some field of the scale. One of them for the field of taxation is the International Tax Competitiveness Index prepared by the Tax Foundation (hereinafter the ITC).

Data for preparation of the ranks could be divided into two groups -soft and hard data. Hard data, could be measured (e.g. the GDP, the unemployment rate) and soft data could be perceived (e.g. influence of taxation on incentives to invest). Sources of hard data are usually globally well established organizations as for example the Organization for Economic Co-operation and Development (hereinafter referred as the OECD), the World Bank or advisory companies like the EY. Sources of soft data are surveys prepared by the organization which issue the competitiveness rank.

In next part of the paper indicators will be briefly described which are related to the taxation and which take place by preparation of the competitiveness indexes.

\section{b. The Global Competitiveness Report}

This report compares over 140 economies all over the world, so it is the most comprehensive assessment of its kind. In this report, each economy is described in detail. The first place in this 
report is occupied by Switzerland, followed by Singapore and the United States. The Czech Republic is on the 31 st place.

Competitiveness of the economy is described by a score which is assigned values from 1 to 7 . The higher the score is, the higher the level of competitiveness of the economy. Competitiveness is defined as "the set of institutions, policies, and factors that determine the level of productivity of an economy, which in turn sets the level of prosperity that the country can earn".

Influence of taxation is reflected in three indicators, but taxation could (indirectly) influence more indexes.

- Indicator Effect of taxation on incentives to invest (No. 6.04) shows extent, to which taxes reduce the incentive to invest. Values of this indicator have a source in the Executive opinion survey prepared by the WEF.

- Indicator Total Tax Rate (No. 6.05) is combination of a profit tax, a labor tax and a social and health insurance contributions and labor taxes paid by the employer), and other taxes (property taxes, turnover taxes, and other small taxes) in the second year of business operation. The source of this data is study Doing Business.

- Indicator Effect of taxation on incentives to work (No. 7.05) shows extent, to which taxes and social contributions reduce the incentive to work. Values of this indicator have a source in the Executive opinion survey prepared by the WEF.

Data for each indicator is publicly available and these indicators are used in the analytic part of the paper together with the total value of competitiveness.

\section{c. World Competitiveness Yearbook}

This competitiveness rank has made public only total results and methodology. It is also possible to browse country by country with information about competitiveness in each category. A higher value of the index means higher competitiveness.

Based on methodology of the IMD, the definition of country's competitiveness is "ability of nations to create and maintain an environment which sustains the competitiveness of enterprises." So this definition is closely connected to the companies located in the economy which should be more competitive. For purpose of this paper, the total value of competitiveness will be used.

\section{d. International tax competitiveness index}

The International tax competitiveness index is focused on the competitiveness in taxation and is issued by the Tax Foundation which is the US independent tax policy research organization focused mainly on the US taxation.

Based on the opinion of the Tax Foundation, country's tax code is an important determinant of economic performance. This index measures competitiveness of the tax policy and also neutrality of the tax policy. Usually, businesses choose the higher rate of return and taxation decreases this rate, so the businesses try to invest in places with lower (marginal) tax rates. High tax rates could be also connected with the tax avoidance. A higher value of the index means higher competitiveness of the country.

The criteria are divided into following groups of taxes: corporate income tax, consumption tax, property tax, individual tax, and international tax rules. As criteria of this index there are used 
e.g. a tax base, (marginal) tax rates, tax burden on labor, possibility of depreciation, tax incentives, a tax loss, taxation complexity, dividends and a withholding tax.

For purpose of this paper will be used values of the total competitiveness and competitiveness if field of corporate and individual income tax, consumption tax, property tax and international taxation.

\section{e. Tax factors which influence the competitiveness}

Country's competitiveness is influenced by many factors. This paper is focused on the influence of taxation on the competitiveness.

The term tax could be interpreted widely or narrowly. Based on the narrow interpretation, each payment is considered as a tax, if defined as a tax in a piece of legislation. According to the wide interpretation, a tax is each payment which meets criteria for a tax - compulsory payment, imposed by law, which is paid into the public budget, is irreversible, unequal and usually nonpurpose (Vančurová and Láchová 2016). Based on this definition, payments of social security and health contributions are also considered as taxes.

The tax rate could be one of the most important indicators based on the literature review. It is also used in international competitiveness ranks. Still, there are more tax rates which should be considered as the indicators. There is a nominal tax rate (stated in the valid tax Act), an effective tax rate (this tax rate also reflects tax base adjustments), an average tax rate (takes into account all subjects in the economy) and a marginal tax rate (a tax rate by which the last unit of income is taxed, usually also the highest applicable rate). The number and width of the tax brackets is closely connected to the tax rate in countries with progressive taxation and also the information from which amount the highest rate is applicable(starting amount of the last tax bracket).

From the corporate income tax point of view, information about carrying loss is important - if it is possible forward and backward, for how many years and what is the maximum amount. From the general point of view, the amount of time, which is needed for handling with all tax matters, is also important information for a tax payer.

\section{Data and methodology}

In previous part of this paper, many sources of competitiveness and its data were mentioned. Based on the aim of the paper, the relationship between competitiveness reports and tax indicators will be analyzed.

Data from the GCR is collected yearly beginning with the year 2006-2007. The indicator 'Total tax rate' is in the ranking from the beginning (from the year 2007); the other indicators ('Effect of taxation on incentives to invest' and 'Effect of taxation on incentives to work') have been analyzed and have been part of the ranking since 2014 .

The data of the International Tax Competitiveness Index are also available beginning with the year 2014. The data from the OECD database and data from the WCY has been available for a longer period, but based on the fact, that many indexes or variables have been available from the year 2014, the data will be analyzed in the period between years 2014 and 2016. However, this fact does not limit the possibility to find a correlation, but it limits the explanatory power of the results. 
From the GCR, values for indicators 6.04, 6.05 and 7.05 and value of competitiveness will be used. From the database WCY, only value of total competitiveness will be analyzed.

The ITC will be used as a source of data about overall score and about each group of factors a corporate income tax (CIT), a personal income tax (PIT), a consumption tax (CON), a property tax (PRO) and international taxation (INT). Higher values of this indicator mean better score and it cannot be interchanged with the tax rate.

From the OECD database, the data about the combined corporate income tax rate, the personal marginal total tax wedge for income in the level of $100 \%$ and $167 \%$ of the average wage and statutory personal income tax rates will be analyzed combined with social security payments and information about top marginal rate for natural persons.

Because of short time period, the panel regression analysis will be not used. Instead of this, data for all 3 periods will be analyzed in one model as regression analysis.

There are many variables (indicators) which could influence the country's competitiveness. So the value of country's competitiveness could be seen as dependence on each of these indicators. For that reason, the following basic equation will be used:

$$
T V=\beta_{0}+\beta_{1} * V_{1}+\cdots+\beta_{n} * V_{n}+\epsilon
$$

Where $\beta_{0}$ is a constant component representing uncorrelated and stable part of relationship between value of country's competitiveness indicators from other competitiveness reports or tax variables, this component is introduced to the model in order to describe influence of other variables; $\beta_{1}$ means effect of indicator $1 ; V_{1}$ is used for value of indicator $1 ; \beta_{n}$ expresses effect of indicator $\mathrm{n} ; V_{n}$ represents value of indicator $\mathrm{n}$, and $\epsilon$ means stochastic term.

The competitiveness is not any a static value and it changes during the time. However, the competitiveness could not be calculated directly from variables, but it has to be compared with other countries and their variables. There is also variability of the values used in the analysis.

For this purpose, the $\log$ - $\log$ analysis will be used and the coefficients $\beta$ is considered as sensitivity of value of country's competitiveness on change of each indicator and the equation (1) will be transformed as follows:

$$
\ln T V=\beta_{0}+\beta_{1} * \ln V_{1}+\cdots+\beta_{n} * \ln V_{n}+\epsilon
$$

Where $\ln T V$ is natural logarithm of value country's competitiveness (GCI, WCY or ITCI); $\ln V_{1}$ means natural logarithm of value of indicator $1 ; \ln V_{n}$ is used for natural logarithm of value of indicator $\mathrm{n}$.

And where:

$$
\beta=\frac{\frac{\Delta T V}{T V}}{\frac{\Delta V}{V}}=\frac{\% T V}{\% V}
$$


After this test, the model and its parameters should be tested. F-test is usually used for testing of the whole model. Each variable is tested for its significance by the t-test. For evaluation of the final model coefficient of determination R2 could be used, which states how much percent of scatter is explained by model (Arlt et al. 2002). The level of statistic significance in this paper is $1 \%$, if not stated otherwise.

It is important to check the multicollinearity. The multicollinearity means, that there is dependence between at least 2 explanatory variables. This can be checked by correlation matrix of explanatory variables. In case of correlation, one explanatory variable has to be eliminated; otherwise estimates of standard errors of the regression coefficients are too high and using both these explanatory variables does not explain any more of the variance (Arlt et al. 2002). Some authors assume that the critical value for multicollinearity is 0,80 .

Multicollinearity occurs between Effect of taxation on incentives to invest (indicator No. 6.04) and Effect of taxation on incentives to work (indicator No. 7.05).

Another case of multicollinearity is between variables of a statutory rate of a personal income tax (PITR) and a personal income tax plus social security contributions (PITR+SSC), between variables of a statutory rate of a personal income tax and a top marginal rate for natural persons and between a personal income tax plus social security contributions and a top marginal rate for natural persons.

Table 1: Used variables in models

\begin{tabular}{|l|l|l|l|}
\hline Variable & Description & Type of data & Source \\
\hline const & Constant & xxx & xxx \\
\hline 1_a6_05 & Total Tax Rate & natural logarithm & GCR \\
\hline 1_a7_05 & Effect of taxation on incentives to work & natural logarithm & GCR \\
\hline 1_ITCI_CIT & Score of corporate income tax index & natural logarithm & ITC \\
\hline 1_ITCI_CON & Score of consumption tax index & natural logarithm & ITC \\
\hline 1_ITCI_PIT & Score of personal income tax index & natural logarithm & ITC \\
\hline 1_ITCI_INT & Score of international taxation index & natural logarithm & ITC \\
\hline 1_ITCI_PRO & Score of property tax index & natural logarithm & ITC \\
\hline 1_OECD_CIT & Corporate tax rate & natural logarithm & OECD \\
\hline 1_OECD_PIT_MAR100 & $\begin{array}{l}\text { Marginal tax wedge for individual with } \\
\text { 100\% of average wage }\end{array}$ & natural logarithm & OECD \\
\hline 1_OECD_PITSS & $\begin{array}{l}\text { Individual tax rate plus social } \\
\text { contribution }\end{array}$ & natural logarithm & OECD \\
\hline
\end{tabular}

Source: GCR, ITC, OECD

\section{Results}

Results are divided into 5 groups based on the indicator used as dependent variable (total value of competitiveness) and source of explanatory variables (tax variables).

\section{a. Indicators from the GCR as explanatory variables for the WCY}

First of all, the analysis is carried out for relationship between tax variables from the GCR as explanatory variables and the dependent variable is total competitiveness from the WCY. In this model, the multicollinearity occurs (please see above).

The results show that there is a positive relationship between competitiveness calculated in the WCY and effect of taxation on incentives to work. However, the model explains only 35 percent of scatter. As the indicator of effect of taxation on incentives to work increases with lower 
influence of taxation, the result is, that taxation has negative impact on the competitiveness. This is in line with the expectation. As the source of this indicator is a survey, this could be the reason, why it has effect on the competitiveness and why it is statistically significant.

Table 2: Results - WCY - variables 6.05 and 7.05

\begin{tabular}{|l|l|l|l|l|}
\hline & Coefficient & Std.Error & p-prob & significance \\
\hline const & 3,97172 & 0,277586 & $<0,0001$ & $* * *$ \\
\hline 1_a6_05 & $-0,0582655$ & 0,0581222 & 0,3186 & \\
\hline 1_a7_05 & 0,433142 & 0,07729 & $<0,0001$ & $* * *$ \\
\hline & & & & \\
\hline $\mathbf{R}^{2}$ & F(2,96) & $\mathbf{n}$ & & \\
\hline 0,352901 & 26,17726 & 99 & & \\
\hline
\end{tabular}

Source: GCR, WCY, own calculation

Note: significance $=$ statistical significant level, $* * *=1 \%, * *=5 \%, *=10 \%$.

\section{b. Indicators from the ITC as explanatory variables for the GCR and the WCY}

In these 2 models as explanatory variables will be used variables from the ITC and as a dependent variable there will be used variables from the GCR and the WCY.

For the GCR, the statistically significant results show positive relationship between some variables from the ITC and competitiveness from the GCR. As the higher value of the GCR means higher competitiveness, the results are also in line with primary expectation, because the taxation has negative impact on the competitiveness. Statistically significant are variables for a consumption tax and international aspects of taxation. Taxation of consumption has the highest influence. However, the results for a corporate income tax, a personal income tax and a property tax have opposite than expected relationship. These variables are not significant and their values are in absolute value really low (in comparison with the statistically significant variables).

Table 3: Results -GCR and WCY - variables ITC

\begin{tabular}{|c|c|c|c|c|c|c|c|c|}
\hline & \multicolumn{2}{|l|}{ Coefficient } & \multicolumn{2}{|l|}{ Std.Error } & \multicolumn{2}{|l|}{ p-prob } & \multicolumn{2}{|c|}{ significance } \\
\hline & GCR & WCY & GCR & WCY & GCR & WCY & GCR & WCY \\
\hline const & 0,838894 & 2,53791 & 0,165046 & 0,310521 & $<0,0001$ & $<0,0001$ & $* * *$ & $* * *$ \\
\hline 1_ITCI_CIT & $-0,00891073$ & 0,0425948 & 0,0322042 & 0,0605896 & 0,7826 & 0,4838 & & \\
\hline 1_ITCI_CON & 0,180625 & 0,34061 & 0,0207863 & 0,0391077 & $<0,0001$ & $<0,0001$ & $* * *$ & $* * *$ \\
\hline 1_ITCI_PIT & $-0,0399204$ & $-0,0721727$ & 0,032577 & 0,0612909 & 0,2235 & 0,2420 & & \\
\hline 1_ITCI_INT & 0,0617196 & 0,067743 & 0,0229256 & 0,0431326 & 0,0084 & 0,1197 & $* * *$ & \\
\hline 1_ITCI_PRO & $-0,00354808$ & 0,0607807 & 0,0282841 & 0,0532142 & 0,9004 & 0,2563 & & \\
\hline & $\mathbf{R}^{2}$ & $F(5,93)$ & $\mathbf{n}$ & & & & & \\
\hline GCR & 0,514987 & 19,74946 & 99 & & & & & \\
\hline WCY & 0,486304 & 17,60817 & 99 & & & & & \\
\hline
\end{tabular}

Source: GCR, WCY, ITC, own calculation

Note: significance $=$ statistical significant level, $* * *=1 \%, * *=5 \%, *=10 \%$.

For the WCY, the statistically significant results show a positive relationship between some variables from the ITC and competitiveness from the WCY. As the higher value of the WCY means higher competitiveness, the results are also in line with primary expectation, because the taxation has negative impact on the competitiveness. Statistically significant is only variable for a consumption tax. However, the results for a personal income tax have an opposite than 
expected relationship. Other variables are not statistically significant and their values are in line with expectation.

In both models with variables from the ITC, the coefficient of determination is quite high around $50 \%$.

\section{c. Indicators from the OECD as explanatory variables for the GCR and the WCY}

In these 2 models there will be used data from the OECD as explanatory variables and as a dependent variables there will be used variables of overall competitiveness from the GCR and the WCY. Because of multicollinearity, the variable for a PIT marginal tax rate for $100 \%$ of average wage and a personal income tax rate plus social security contribution is used (please see above).

For the GCR, the statistically significant results show a positive relationship between some variables from the OECD and competitiveness from the GCR. As the higher value of the GCR means higher competitiveness, the results are not in line with primary expectation, because the higher taxation has positive impact on the competitiveness. Statistically significant is only variable for taxation of natural person (combination of a personal income tax and social security contributions). The results for a corporate income tax and a marginal personal income tax for $100 \%$ of average wage are also not in line with expectation, but they are not statistically significant.

Table 4: Results - GCR and WCY - variables OECD

\begin{tabular}{|c|c|c|c|c|c|c|c|c|}
\hline & \multicolumn{2}{|l|}{ Coefficient } & \multicolumn{2}{|l|}{ Std.Error } & \multicolumn{2}{|l|}{ p-prob } & \multicolumn{2}{|c|}{ significance } \\
\hline & GCR & WCY & GCR & WCY & GCR & WCY & $\begin{array}{l}\text { GC } \\
\mathbf{R}\end{array}$ & $\begin{array}{l}\text { WC } \\
\mathbf{Y}\end{array}$ \\
\hline const & 0,875022 & 3,52248 & 0,188584 & 0,362449 & $\begin{array}{c}<0,000 \\
1\end{array}$ & $\begin{array}{c}<0,000 \\
1\end{array}$ & $* * *$ & $* * *$ \\
\hline 1_OECD_CIT & 0,060291 & 0,0434321 & 0,040014 & $\begin{array}{c}0,076905 \\
3\end{array}$ & 0,1352 & 0,5736 & & \\
\hline $\begin{array}{l}\text { 1_OECD_PIT_MAR10 } \\
0\end{array}$ & $\begin{array}{c}0,00055385 \\
2\end{array}$ & $\begin{array}{c}-0,000104 \\
8\end{array}$ & 0,025922 & $\begin{array}{c}0,049822 \\
6\end{array}$ & 0,9830 & 0,9983 & & \\
\hline 1_OECD_PITSS & 0,138408 & 0,166325 & $\begin{array}{c}0,046178 \\
4\end{array}$ & $\begin{array}{c}0,088752 \\
7\end{array}$ & 0,0035 & 0,0640 & $* * *$ & $*$ \\
\hline & $\mathbf{R}^{2}$ & $F(3,95)$ & $\mathbf{n}$ & & & & & \\
\hline GCR & 0,141363 & 5,213504 & 99 & & & & & \\
\hline WCY & 0,050975 & 1,700916 & 99 & & & & & \\
\hline
\end{tabular}

Source: GCR, WCY, OECD, own calculation

Note: significance $=$ statistical significant level, $* * *=1 \%, * *=5 \%, *=10 \%$.

For the WCY, the statistically significant results show a positive relationship between some variables from the OECD and competitiveness from the WCY. As the higher value of the WCY means higher competitiveness, the results are not in line with primary expectation, because the high taxation has positive impact on the competitiveness. Statistically significant is only variable for taxation of natural person (combination of a personal income tax and social security contributions) on level of $10 \%$ of statistical significance. However, the results for a marginal personal income tax for $100 \%$ of average wage have an expected relationship. Variable for a corporate income tax is not statistically significant and its value is not in line with expectation. 
In both models with variables from the OECD, the coefficient of determination is low- not higher than $15 \%$.

\section{Discussion and conclusion}

The aim of this paper was to analyze the relation between the country's competitiveness and tax variables. Values of competitiveness from global ranks of competitiveness were used as the explained variables. As explanatory variables there were used variables from competitiveness reports and data from the OECD statistic. This analysis was carried out for the period between 2014 and 2016, because many indicators were available for this period.

Conclusion of all tests carried out in this paper is not clear because tests show different results and relationship between the explained variable and explanatory variables. One could expect that the relationship between the tax rate and competitiveness will be negative.

The model with indicators from the GCR (and explained variable is the WCY) shows that the only statistically significant variable is the Effect of taxation on incentives to work. A higher value of this indicator means lower influence of taxation on competitiveness. The relationship is positive and this is in line with the expectation. As the source of this indicator is a survey, this could be the reason, why it has effect on the competitiveness, because the respondents could feel better how taxation affects the competitiveness of the economy.

The second set of models was carried out with explanatory variables from the ITC and the explained variables were values of competitiveness from the GCR and the WGY. The indicators from the ITC reflect more impacts than only the tax rate and higher value means higher competitiveness.

In both models, the variable related to the consumption tax was statistically significant. In the test with the explained variable from the GCR, influence of international taxation was also statistically significant. All the statistically significant relationships are positive and this is also in line with our expectations. Based on the results of these models, variables of a corporate income tax and an individual income tax are negative (meaning, that increasing these values it is not the tax rate, but the complex variable and higher values mean a better result- a decrease of the competitiveness. However, these variables are in absolute value really low. These models have also a coefficient of determination around $50 \%$, so these variables explain almost half of the variability.

As the third kind set of models, the explanatory variables of tax rates are taken from the OECD database and these data are tested with competitiveness from the GCR and the WGY. Statistically significant is only combination of a personal income tax and social security contributions - in the model with the WGY only on $10 \%$ level of statistical significance.

These models show interesting results, because higher tax rates lead to the higher competitiveness. These results are not in line with our expectations and economic theory. One could expect, that higher tax rate (and higher tax liability) decrease net income of the company so it decrease the net return of capital. The explanation could be that the higher tax rate is not an important variable or that persons expect with a higher tax rate higher level of public goods. These models also have a quite low coefficient of determination - not higher than $15 \%$.

One explanation could be also the fact, that the tax revenue is used by the government for public services and other public goods, which has positive effects - e.g. better roads, better health care 
system etc. and these public goods and services might increase motivation of the employees and decrease costs of the company (better roads means lower costs of car repairs).

As the direction of the relationship (negative or positive) between competitiveness and taxation is unclear, there should be a deeper analysis. It is also recommendable to carry out an analysis, which should measure competitiveness not by the world-wide ranks, but rather by other (economic) variables - e.g. the GDP, the GPD per capita, the economic growth, and foreign direct investments. This could solve problems with the definition of competitiveness (as many definitions of competitiveness are available).

\section{Acknowledgement}

The contribution is processed as an output of a research project Public finance in the Czech Republic and the EU under the registration number F1/1/2016.

\section{References}

[1] AIGINGER, K., S. BÄRENTHALER-SIEBER and J. VOGEL, 2013. Competitiveness under New Perspectives.

[2] ARLT, J., M. ARLTOVÁ a E. RUBLÍKOVÁ, 2002. Analýza ekonomických časových řad $s$ príklady. Vysoká škola ekonomická, Fakulta informatiky a statistiky, Praha.

[3] BALASSA, B., 1964. The Purchasing-Power Parity Doctrine: A Reappraisal. J. Polit. Econ. 72, 584-596. https://doi.org/10.1086/258965

[4] BARANOVA, V. and L.JANICKOVA, 2012. Taxation of Corporations and Their Impact on Economic Growth: The Case of EU Countries. J. Compet. 4, 96-108. https://doi.org/10.7441/joc.2012.04.07

[5] BARRO, R., 1998. Notes on Growth Accounting (No. w6654). National Bureau of Economic Research, Cambridge, MA. https://doi.org/10.3386/w6654

[6] CELLINI, R. and A. SOCI, 2002. Pop competitiveness. Banca Naz. Lav. Q. Rev. 2002.

[7] DJOGO, M. and N. STANISIC, 2016. IS THE GLOBAL COMPETITIVENESS REPORT THE RIGHT MEASURE OF MACROECONOMIC COMPETITIVENESS. Zb. Rad. Ekon. Fak. U Rijeci Časopis Za Ekon. Teor. Praksu Proc. Rij. Fac. Econ. J. Econ. Bus. 34, 91117. https://doi.org/10.18045/zbefri.2016.1.91

[8] JOHANSSON, Å., C. HEADY, J. ARNOLD and B. BRYS, 2008. Taxation and Economic Growth.

[9] JUDD, K. L., 1985. Redistributive taxation in a simple perfect foresight model. J. Public Econ. 28, 59-83. https://doi.org/10.1016/0047-2727(85)90020-9

[10] KANBUR, R. and M. KEEN, 1993. Jeux Sans Frontières: Tax Competition and Tax Coordination When Countries Differ in Size. Am. Econ. Rev. 83, 877-892.

[11] KRUGMAN, P., 1994. Competitiveness: A Dangerous Obsession. Foreign Aff. 73, 28. https://doi.org/10.2307/20045917

[12] LIAPIS, K. J., C. L. GALANOS and E. D. POLITIS, 2014. A Quantitative Approach to Measure Tax Competitiveness Between EU Countries. Int. J. Econ. Sci. Appl. Res. 7, 723.

[13] MALÝ, J., 2011. Globalizace, integrace a české národní zájmy. Professional Publishing, Praha. 
[14] PÂRTACHI, I. and E. GÂRLA, 2016. Economic competitiveness in the regional and global context. Romanian Econ. Bus. Rev. 11, 100.

[15] SMITH, E. and T. J. WEBB, 2001. Tax Competition, Income Differentials and Local Public Services. Int. Tax Public Finance 8, 675-691.

[16] TYSON, L. D., 1993. Who's bashing whom? trade conflicts in high-technology industries. Institute for International Economics, Washington, DC.

[17] VANČUROVÁ, A. a L. LÁCHOVÁ, 2016. Daňový systém ČR 2016.

[18] WILSON, J. D., 1999. Theories of tax competition. Natl. Tax J. 1999. 